\title{
A proposal for improving safety in construction projects by strengthening coordinators' competencies in health and safety issues
}

\author{
Ros Serrano Antonio Ortiz-Marcos Isabel Palomo Sánchez José Gabriel Uruburu Colsa Angel
}

\begin{abstract}
A B S T R A C T
The figure of the coordinator in health and safety issues in the construction sector first appeared in our legislation through the incorporation of the European Directives (in our case Royal Decree 1627/97 on the minimum health and safety regulations in construction works), and is viewed differently in different countries of the European Union regarding the way they are hired and their role in the construction industry.

Coordinating health and safety issues is also a management process that requires certain competencies that are not only based on technical or professional training, but which, taking account of the work environment, require the use of strategies and tools that are related to experience and personal skills. Through a piece of research that took account of expert opinions in the matter, we have found which competencies need to be possessed by the health and safety coordinator in order to improve the safety in the works they are coordinating. The conclusions of the analyses performed using the appropriate statistical methods (comparing means and multivariate analysis techniques), will enable training programmes to be designed and ensure that the health and safety coordinators selected have the competencies required to carry out their duties.
\end{abstract}

\section{Introduction}

Spain has one of the highest accident rates in the construction sector of all the countries in Europe although, in contradiction, it has far-reaching and relatively innovative legislation.

Construction work is also considered high-risk in the European context. As a result, the European Communities Council in its Resolution of 21 December 1987, named the construction sector as one of the three highest risk sectors and instructed the Commission to prepare a Directive which culminated in the directive identified as 92/57 CEE, of 24 June 1992 on construction work, and was incorporated into our legal system through RD 1627/97 of 24 October. Some interesting analyses of regulatory tools in some European countries have been published (Zwetsloot et al., 2011a,b), as well as a review of the rules and regulations on safety in the countries of the European Union (Leka et al., 2011; Esteban Gabriel, 2011).

This legal framework formed what is now known as preventive management in construction works. It defines the obligations in health and safety matters of the different players intervening in the construction process (promoters, project engineers, safety coordinators, contractors, sub-contractors and self-employed workers). It also gave rise to the figure of the health and safety coordinator during the project and construction stages, whose job is to help health and safety be integrated into the different construction process stages.

Productivity in the construction sector is deemed to be one of the most aggressive for workers. The accident rate figures for Spain go beyond statistics and have become a real social concern. Although most accidents happen in small enterprise, with the greatest impact being in medium enterprise, it is the major construction companies that employ the highest number of labourers and skilled and temporary workers and is therefore the group that suffers the highest accident and accidentality rate with its serious human, social and family consequences, (Durán López et al., 2007).

One of the fundamental figures in construction work regarding safety is the Health and Safety Coordinator. Having examined the state-of-the-art of the works that have been published on health and safety, it has been seen that they give thorough coverage (Beguería Latorre, 2002; Anduiza Arriola et al., 2004; Perona Lucas, 2005; Mármol Ortuño and Pérez Herrero, 2007; Baker, 2011), to the duties and jobs for which the health and safety coordinator is responsible. Sometimes they also approach (Törner, 2011; Kristensen, 2011) the way the organisational model can affect safety and put forward management mechanisms and models to improve safety. 
However, in the above works examined, there is no explicit approach to the techniques, skills, tools and competencies that this player must be familiar with and apply to their job activity.

This paper is the result of research that was conducted in the construction sector in Spain and developed at the Universidad Politécnica de Madrid in order to find the most important competencies required by Health and Safety Coordinators for them to be able to comply with what is legally demanded of them. The results of this research, discussed in this paper, will enable the training programmes of these professionals to be enhanced by showing them how to strengthen these competencies. By combining duties with competencies, it will help select those experts who will achieve their objective of improving safety in the most effective way.

This paper is structured in six sections. The first gives the definitions of the competencies that will help the understanding of this study, as well as an outline of the training currently required for health and safety coordinators and their most characteristic features. The second section describes the methodology used to develop the research, and the third the results obtained. In the fourth section, the results are interpreted. Finally, section five presents the conclusions of the research and section six, the reference bibliography.

\subsection{Competencies and competent}

Boyatzis (1982) defines a competence as "as an underlying characteristic in a person that is causally related with good or excellent performance in a specific job position in a specific organisation". Spencer and Spencer (1993) are of the opinion that a competence is: "an underlying characteristic of a person that is causally related to an effective or higher performance in a specific situation or job, defined in terms of a criterion". Woodruffe (1993) sees it as "a dimension of open and manifest behaviours that enable a person to perform efficiently". Rodríguez and Feliú (1996a,b) define it as "sets of knowledge, skills, dispositions and behaviours that a person possesses that enable them to successfully carry out an activity". Ansorena Cao (1996) is of the opinion that it is: "a skill or personal attribute of a subject's conduct which may be defined as a characteristic of their behaviour and under which, the behaviour oriented towards the job can be classified as logical and reliable". Guión (cited in Spencer and Spencer) defines it as "people's underlying characteristics that indicate ways of behaving or thinking that can be generalised to one situation or another and which are maintained for a reasonably long time".

From an analysis of these definitions, it may be concluded that Competencies:

1. Are permanent characteristics of a person.

2. Are made manifest when performing a task or doing a job.

3. Are related to the successful performance of an activity, either work or of another kind.

4. They have a causal relationship with job performance, that is, they are not only associated with success, but it assumed that they are the cause of it.

5. They can be generalised to more than one activity.

\subsection{Training the health and safety coordinator}

Training the coordinator in health and safety issues is not regulated in Spain, nor is there any mutual agreement with most of the organisations or trainers that are involved in this work.

According to the criteria of the Technical Guidelines produced by the National Institute of Safety and Hygiene at Work on RD $1627 / 97$, on the minimum conditions of health and safety in construction works, in Appendix B there is a $200 \mathrm{~h}$ training course that the coordinator must be familiar with; however, this text is not binding.

In some qualifications, such as the Technical Architect degree, there are subjects that teach some general information about the figure of the coordinator. In the current model of the European Higher Education Area, the competencies required to carry out a coordinator's duties is specified in some degrees, which is the case of Construction Engineering (Segarra Cañamares and Amat Batlle, 2011).

It is clear that in Spain, a health and safety coordinator's training requires a university background that will prepare them to be a qualified expert and ensure they have the ability to perform the tasks laid down in current legislation. However, what is laid down not only requires this expert to have the right studies and abilities but also requires them to have practical a knowledge and experience of construction processes, and moreover, to have experience of the reality of construction works. Therefore, we are committed to this latter characteristic, which will give meaning to the job position by making it part of the same production process as the other players.

\subsubsection{Characteristics of the coordinator}

The Coordinator is therefore, a competent expert with specific characteristics. They need to (Vedsmand, 2011; Anduiza Arriola et al., 2001):

- be familiar with construction techniques and processes

- know how to work on cost optimisation

- have a thorough understanding of the work being coordinated so that they can undertake organisation and coordination tasks

- be a good negotiator

- be able to communicate and be effective in their work

- relate well to all the players in the process

According to the Law, the DUTIES of a coordinator in health and safety issues in the construction stage, which are set out in article 6 of Directive 92/57/CEE, must pass through the approval stage or if the works are for the Administration they are subject to the approval of a report written by the contractor on the health and safety plan and any changes (CONSEJO DE LA UNIÓN EUROPEA, 2007).

The duties are specified and laid down in Article 9 of Royal Decree 1627/97:

- to coordinate the implementation of the general principles of health and safety

- to coordinate the job activities

- to approve the health and safety plan

- to organise the coordination of the business activities

- to coordinate supervisory actions and duties

- to take the necessary measures to ensure that only authorised personnel have access to the work site.

The European Directives referring to coordination duties in the different countries of the European Union have undergone few changes that affect the coordinator's duties. They have mainly affected formal documents and standards linked to corrective actions.

There is a clear gap regarding the characteristics of the coordinator as laid down in Law in this Section, since the duties and obligations of the coordinator as well as being related to construction techniques (technical competencies), are of a more personal nature (behavioural competencies), which will undoubtedly enrich their job productivity and effectiveness.

All the above leads to a reflection on the kind of training a coordinator requires before confronting the arduous task of becoming part of a highly unstable, highly complex process where the 
relationships with the other players are very different, difficult and sometimes unrewarding.

\section{Methodology}

The methodology adopted to find the most important competencies required for carrying out a coordinator's duties in health and safety issues, has been developed by analysing the results obtained from a survey given to health and safety coordinators.

\subsection{Research stages}

After conducting the above-mentioned survey among health and safety coordinators to find models to explain the relationship between competencies and coordination duties so that the latter would run more smoothly, thereby improving the coordinator's job tasks, the results of these surveys were statistically interpreted. The research stages are shown in Fig. 1.

\subsection{Sample and survey characteristics}

It is difficult to be exact as to the size of the population from which the sample was taken as there is no coordinators census at a national level. Moreover, the wide range of professions that are authorised to carry out these duties (architecture, technical architecture, engineering and technical engineering, according to the Town Planning and Development Act), do not provide any information on this issue. In order to obtain the sample, the questionnaires referred to in this paper were submitted to the different Official and Professional Bodies using different methods. Table 1 shows the characteristics of the sample under study.

Eighty-six percentage of those polled have a technical architecture-related job, which is quite reasonable, since coordination work is mainly done by professionals who are in possession of this qualification.

The individuals polled have between one and 46 years' experience.

The aims of this paper are focused on the relationship between individual competencies and the duties of the coordinator in questions of health and safety. The aim is to improve the action methodology, strengthen prevention management and, therefore, improve on-site work safety. It is therefore not aimed at applying safety at work by adopting corrective actions to reduce accidents. This means that coordinators' experiences are valid for any category of work or branch of construction by following the guidelines set by the project's management.

Closed questions were used in the questionnaire designed to prepare this study where those polled were asked to score the level of importance of the competencies on a 1-5 scale, on the one hand (questionnaire $\mathrm{A}$ in the appendix) and on the other hand, the importance of the coordination duties and activities (questionnaire $B$ in the appendix).

When designing the questions in the survey, what was firstly borne in mind were the duties laid down in Article 9 of RD 1627/ 97 on the minimum health and safety requirements in construction works and the changes undergone by these regulations in recent years. Questions were also asked regarding the competencies required by coordinators. To establish what these competencies were, some existing competence certification models were examined, specifically the models of the Project Management Institute (PMI) and the International Project Management Association (IPMA) for the certification of competencies required by project managers (Udo and Koppensteiner, 2004).

Apart from international standards, many authors have set competence frameworks grouped together according to different scopes, sectors or project type: general project management competencies for project-oriented organisations Kasvi et al. (2003), Crawford (2005) and Jha and Iyer (2007); the identification of organisational competencies for their successful management (Gareis, 2003; Escrig-Tena and Bou-Llusar, 2005; Schmeidinger, 2005; Zibell, 2007; Shirazi and Mortazavi, 2009); the identification of competencies for human resources selection processes (Udo and Koppensteiner, 2004; Eicker et al., 2007) or the identification of competencies by project type (in the construction context (Andrew et al., 2004; Kwaku et al., 2008), for medicine (Cook et al., 2008) and software projects (Rose et al., 2007)).

Identifying the competencies for project management in the works analysed was generally done through interviews with experts or case studies.

Taking these models as a basis, a work session with experts was held where any competencies that were not deemed relevant were eliminated and those deemed relevant according to the experts' experience, were accepted.

After this session and using the judgment of these experts as a basis, the final questionnaire was produced (see appendix). This questionnaire was the indispensable tool for carrying out the developed research.

The Likert scale was used to score both questionnaires. This is a psychometric scale commonly used in questionnaires and very frequently in research questionnaires. (Likert, 1932). Data processing was performed using the STATGRAPHICS 5.1 Plus computer program.

A Likert-type element is a statement given to the subjects so it can be evaluated according to their subjective criteria; the subjects are usually asked to express their degree of agreement or disagreement. The usual procedure, which was followed in this questionnaire, is to use five possible responses or levels of agreement or disagreement.

Table 2 contains the competencies and duties of the health and safety coordinator, which is the subject of this analysis.

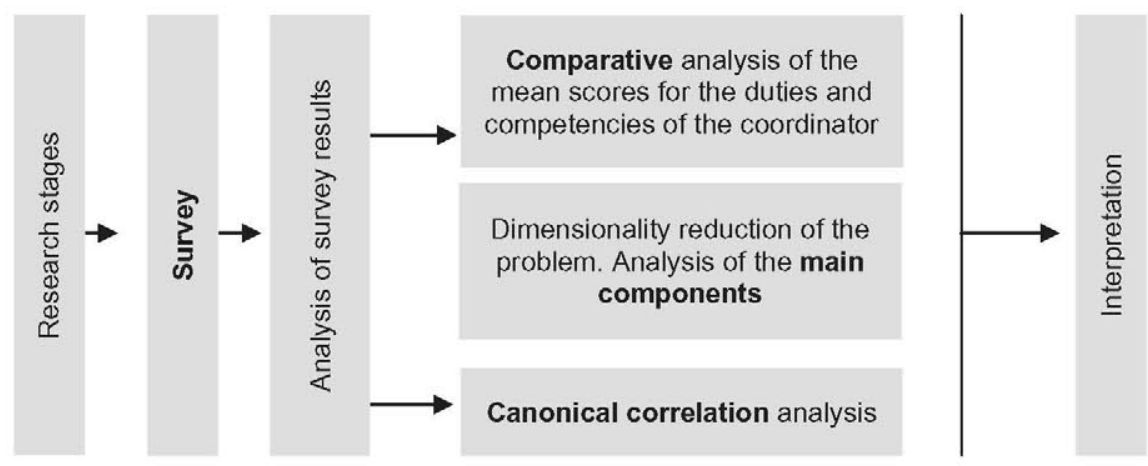

Fig. 1. Research stages. Own research. 
Table 1

Sample under study. Own research.

\begin{tabular}{cl}
\hline Population & $\begin{array}{l}\text { Professionals from the construction sector } \\
\text { Health and safety coordinators during the construction stage } \\
\text { Sample }\end{array}$ \\
$\begin{array}{c}130 \text { Individuals selected from coordination courses, } \\
\text { professional bodies and experts via email and face-to-face }\end{array}$ \\
$\begin{array}{c}\text { Purified } \\
\text { sample }\end{array}$ & $\begin{array}{l}126 \text { Individuals for questionnaire A, coordination duties } \\
\text { coordinator } \\
125 \text { Individuals for the joint analysis of both questionnaires }\end{array}$
\end{tabular}

Table 2

Competencies and duties of the health and safety coordinator. Own research.

\begin{tabular}{ll}
\hline $\begin{array}{l}\text { Personal and } \\
\text { behavioural } \\
\text { competencies }\end{array}$ & $\begin{array}{l}\text { Coordinator's duties in health and safety issues } \\
\text { during the construction stage }\end{array}$ \\
\hline $\begin{array}{l}\text { 1. Communication } \\
\text { 2. Teamwork }\end{array}$ & $\begin{array}{l}\text { 1. To coordinate the application of the general } \\
\text { principles of health and safety at work }\end{array}$ \\
$\begin{array}{l}\text { 2. To coordinate on-site activities } \\
\text { 3. Effectiveness }\end{array}$ & $\begin{array}{l}\text { 3. To approve the health and safety plan } \\
\text { 4. Efficiency }\end{array}$ \\
$\begin{array}{l}\text { 4. To organise the coordination of business } \\
\text { activities }\end{array}$ \\
$\begin{array}{ll}\text { 6. Self-control } & \text { 5. To organise supervisory actions and duties } \\
\text { 7. Solving conflicts and } & \text { 6. To take measures to control site access } \\
\text { 7. Leadership } & \text { 7. To use the incidents book } \\
\text { 9. Consultation } & \text { 8. To give instructions } \\
\text { 10. Negotiation } & \text { 9. Meetings with clients } \\
\text { 11. Results-oriented } & \text { 10. Meetings with other players in the process } \\
\text { 12. Planning and } & \text { 11. Coordination meetings } \\
\text { organisation } & \text { 12. Site visits } \\
\text { 13. Commitment to the } & \text { 13. Report writing } \\
\text { project } & \text { 14. To act in the event of an accident }\end{array}$ \\
\end{tabular}

\section{Results}

Using appropriate statistical methods (comparing means and multivariate analysis techniques), this section presents the results of the different analyses of the data obtained from the survey. The aim of these analyses is firstly to separately compare the mean scores obtained for the duties and competencies in a way that differentiates the duties and competencies most highly and lowly rated by those polled. Secondly, a separate analysis will also be made of the main components, the object of which will be to reduce the spatial dimensionality of the data to find a small set of duties and competencies that explain a high percentage of the total variability of both sets of variables. Finally, a canonical correlation analysis will be performed in order to find linear combinations of duties that correlate highly with linear combinations of competencies. This analysis will lead to a search for the specific competencies required to facilitate a good performance of specific coordination duties.

\subsection{Comparing means}

As indicated in point 2.2, all those polled were asked to score, on a 1-5 scale, the level of importance they gave to each of the competencies under analysis, with a view to strengthening health and safety coordination. They were also asked to score, on the same scale, the level of importance they gave to each of the duties and activities carried out by the health and safety coordinator.

In order to discuss whether, on average, all the competencies and duties were similarly scored, or to the contrary, there were any significant differences in scores, both were subjected to multiple mean comparison analysis. The method used was Fisher's least significant differences procedure (LSD). A summary of the results obtained for the duties and the competencies are presented separately in the following points.

This analysis clearly indicates which means may be significantly different from the general mean, and shows which competencies and which duties have been given a significantly higher or lower mean score than the rest.

\subsubsection{Competencies}

The following means analysis graph for competencies (Graph 1), shows the sampling mean for the scores obtained for each competence. The middle line of the graph coincides with the global mean for all the scores, $y=3.96$, and the decision lines $L C L=3.75$ and $U C L=4.17$, were obtained by adding and subtracting the standard deviations from the mean, $\sigma \approx 0.07$, estimated by taking the total of all the scores.

The values that are above the UCL upper decision limit or below the LCL lower decision limit, point out the competencies that are scored as significantly different from the general mean. The remaining values included in the UCL-LCL band refer to competencies whose score is not significantly different from the general mean.

From this graph it can be deduced that the competencies most significantly scored by those polled are competence 1 (communication) and 13 (commitment to the project).

The least significantly scored competencies were 5 (self-control) and 8 (leadership), clearly below the general mean. It should be pointed out that effective leadership, in the opinion of some authors, (Eid et al., 2011; Martínez-Córcoles et al., 2011; Boyatzis, 2009), is strongly related to safety. Although, this competence has been significantly scored below the mean in this first analysis, in a subsequent analysis its importance will be demonstrated from other points of view.

In respect of the other competencies, there is no evidence that their scores are different from one another or different from the general mean.

\subsubsection{Duties}

The following graph (Graph 2) summarises the results obtained for duties in a similar analysis to the one in the preceding section.

In this case, the global mean for all the scores was $y=3.90$, and the decision lines $L C L=3.68$; $U C L=4.11$, and $\sigma \approx 0.07$.

In respect of the scores for the coordination duties, from the diagram it can be seen that all the duties have been highly scored, with a very high percentage of scores between 3 and 5 . In every case the mean is 4 .

If we compare the duties with one another to evaluate the importance given by the individuals polled, the highest score went to duty number 12 (site visits) and 14 (action to take in the event of an accident). Also highly scored were duties 2 (coordinating on-site activities), and 1 (Coordinating the application of the general principles of health and safety).

The lowest scores went to number 15 (awareness raising talks), 13 (report writing), 9 (meetings with clients) and 6 (site access).

\subsection{Principal components analysis}

The Principal Components Analysis (PCA) is a statistical technique for synthesising information or for reducing the dimensionality of the problem (number of variables). That is to say, when faced with a data bank containing many variables, the aim is to reduce them to a lesser number but losing the least possible amount of information, so as to be able to explain the variability of the original data set. The new "principle components" variables will be a 


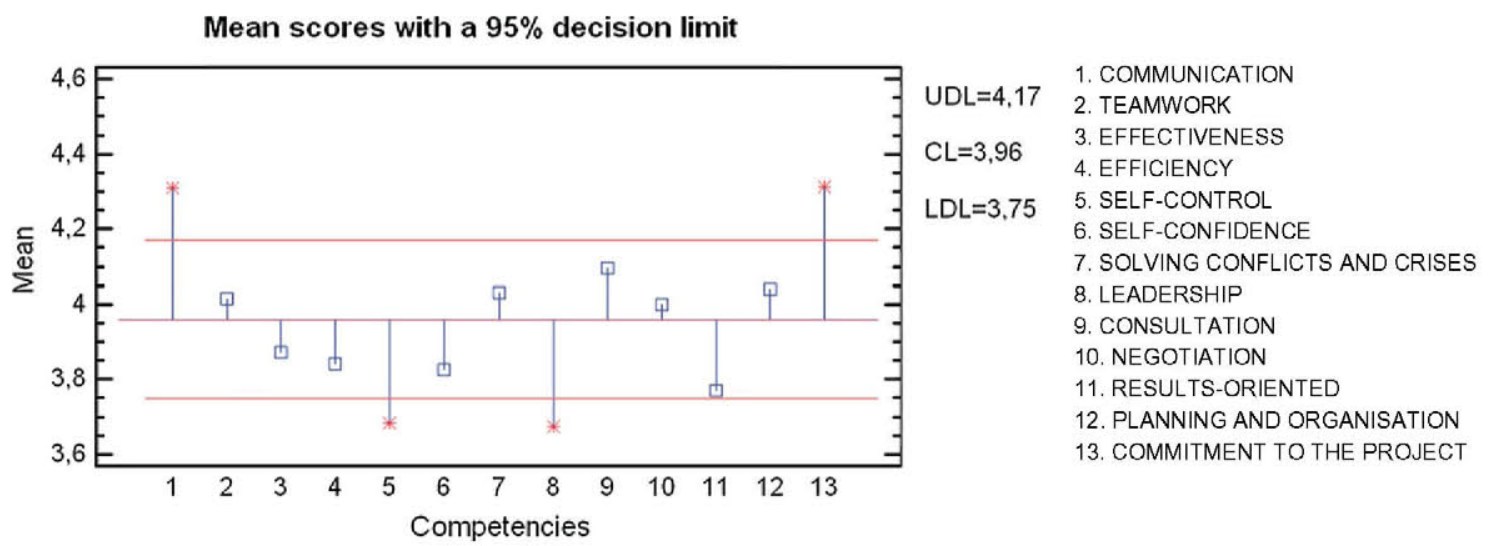

Graph 1. Means graph for competencies. Own research.

linear combination of the original variables and will also be independent of one another. A key aspect of PCA is the interpretation of the components since this is not given a priori, but has to be deduced after seeing how these components are related to the initial variable.

Regarding COMPETENCIES, Table 3 lists the coefficients of the first three components in respect of the different competencies. It also lists the percentage of variability attributed to each competence and the total variability (53.569\%) explained as a whole for these three components.

By way of example, we can show that the equation of the first component is:

\section{$C_{1}=0.232742$. communication +0.278611 .teamwork $+\ldots$}

\section{+0.259603 .commitment to the project}

The italicised numbers in Table 3 shows the competencies that have the most weight in the linear combination defining the main component.

Although there are thirteen main components, in this analysis only the first three have been considered to explain over $50 \%$ of the total variability. From the third component on, the variability explained by the other components tends to stabilise, as can be seen from the following sedimentation graph (Graph 3 ).

Regarding DUTIES, Table 4 lists the coefficients of the first four components as well as the percentage of variability attributed to each of them together with the total variability (54.46\%) explained as a whole for these four components.

By way of example, we can show that the equation of the first component is:

$C_{1}=0.218362$.coordinating PPGG PRL application

+0.197011 .coordinate site activities $+\ldots$

+0.27072 .awareness - raising talks

The italicised numbers in Table 4 shows the competencies that have the most weight in the linear combination defining the main component.

Although there are fifteen main components, in this analysis only the first four have been considered to explain, as with the competencies, over $50 \%$ of the total variability. From the fourth component on, the variability explained by the other components tends to stabilise, as can be seen from the following sedimentation graph (Graph 4).

\subsection{Canonical correlations}

Now having two sets of variables, which in this work correspond to the scores given by those polled on the competencies to be acquired by the coordinators and on the duties they legally and socially carry out, the purpose of the canonical correlation methodology is to find linear combinations that correlate highly from both sets of variables.

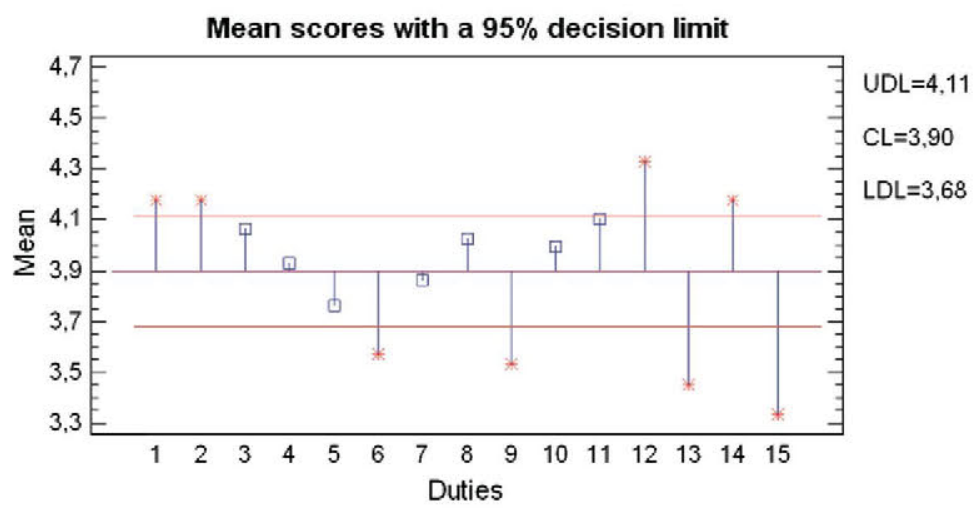

\author{
1. COORDINATE APPLICATION OF SAFETY \\ PRINCIPLES \\ 2. COORDINATE SITE ACTIVITIES \\ 3. APPROVE THE H \& S PLAN \\ 4. ORGANISE BUSINESS ACTIVITIES \\ COORDINATION \\ 5. COORDINATE SUPERVISORY ACTIONS AND \\ DUTIES \\ 6. ADOPT SITE ACCESS MEASURES \\ 7. USE INCIDENTS BOOK \\ 8. GIVE INSTRUCTIONS \\ 9. MEETINGS WITH CLIENTS \\ 10. MEETINGS WITH PLAYERS \\ 11. COORDINATION MEETINGS \\ 12. SITE VISITS \\ 13. REPORT WRITING \\ 14. ACTION TO TAKE IN THE EVENT OF AN \\ ACCIDENT \\ 15. AWARENESS RAISING TALKS
}


Table 3

Results obtained from the principle components analysis on the COMPETENCIES variables. Own research.

\begin{tabular}{|c|c|c|c|c|}
\hline \multicolumn{2}{|c|}{ Competencies } & \multirow{2}{*}{$\begin{array}{l}\text { Component } 1 \\
0.232742\end{array}$} & \multirow{2}{*}{$\begin{array}{l}\text { Component } 2 \\
0.268531\end{array}$} & \multirow{2}{*}{$\begin{array}{l}\text { Component } 3 \\
0.117296\end{array}$} \\
\hline 1 & Communication & & & \\
\hline 2 & Teamwork & 0.278611 & 0.291832 & 0.0361255 \\
\hline 3 & Effectiveness & 0.293599 & 0.410346 & -0.0826729 \\
\hline 4 & Efficiency & 0.250017 & 0.498598 & -0.193314 \\
\hline 5 & Self-control & 0.302166 & -0.0495735 & 0.0700247 \\
\hline 6 & Self-confidence & 0.244825 & -0.15819 & 0.512075 \\
\hline 7 & Solving conflicts and crises & 0.298063 & -0.320198 & -0.0302368 \\
\hline 8 & Leadership & 0.317629 & -0.0128761 & 0.120724 \\
\hline 9 & Consultation & 0.285914 & -0.393682 & -0.313248 \\
\hline 10 & Negotiation & 0.335701 & -0.333154 & -0.18307 \\
\hline 11 & Results-oriented & 0.283848 & 0.0957909 & -0.305462 \\
\hline 12 & Planning and organisation & 0.190049 & -0.00765624 & 0.650213 \\
\hline \multirow[t]{2}{*}{13} & Commitment to the project & 0.259603 & -0.142676 & -0.101962 \\
\hline & Percentage variability attributed total $\mathbf{5 3 . 5 6 9 \%}$ & $34.019 \%$ & $10.75 \%$ & $8.80 \%$ \\
\hline
\end{tabular}

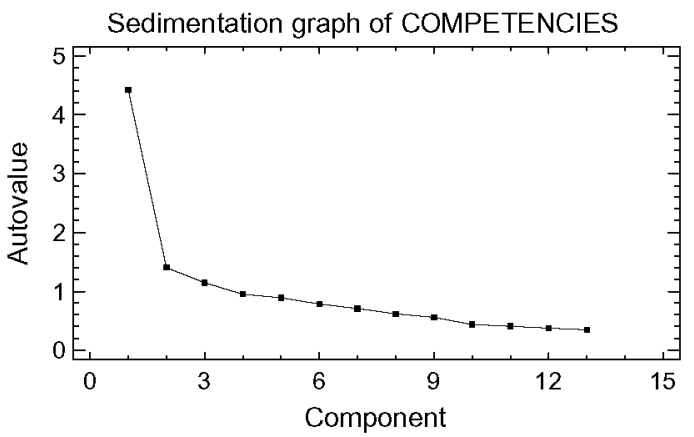

Graph 3. Sedimentation of competencies. Own research.

Ultimately, if we take account of the set of all the competencies $\left(C_{1}, \ldots, C_{13}\right)$ and the set of all the coordination duties $\left(F_{1}, \ldots, F_{15}\right)$, what is required is to find linear combinations of the second set $b_{i 1-}$ $F_{1}+, \ldots,+b_{i 15} F_{15}$, so that the correlation between these linear combinations is maximum. Each of the linear combinations is a canonical correlation.

Each of the linear combinations of the sets of competencies and the sets of duties in turn defines non-observable variables (fictitious). The pairs formed by these variables are the canonical correlations.

Table 5 shows the $p$-values that measure the significance of the different canonical variables and the correlation coefficients between the different pairs of canonical correlations obtained.
Of all the possible canonical correlations, which are thirteen in this case, it can be seen that there are three significant canonical correlations at $95 \%, p$-value $<0.05$

The italicised numbers in Table 6 shows the competencies and duties that have the most weight in the linear combination defining the main component or the correlation.

The relationships in the three canonical correlations are shown in Table 7.

\section{Interpreting the results}

\subsection{Means comparison analyses}

From the results obtained, the following interpretations can be made regarding the means comparison analyses of the COMPETENCIES:

- The fact that those polled have given a higher score to the communication competence is logical and closely linked to the work done by a health and safety coordinator, since, either verbally or in writing they have to relate to the other players that intervene in the construction process.

- The commitment to the project and consultation competences can be interpreted likewise, as a fundamental job of the coordinator is to carry out work associated with both competencies. These two competencies must be related to others that have not been scored the same but which are linked to them, such as teamwork and negotiation.

Table 4

Results obtained from the principle components analysis on COORDIANTION DUTIES. Own research

\begin{tabular}{rlllll}
\hline Duties & & Component 1 & Component 2 & Component 3 & Component 4 \\
\hline 1 & Coordinate application of safety principles & 0.218362 & -0.348745 & -0.0162942 & 0.014893 \\
2 & Coordinate site activities & 0.197011 & -0.284396 & -0.132862 & 0.305475 \\
3 & Approve the H \& S plan & 0.228957 & 0.0117804 & -0.439953 & -0.22512 \\
4 & Organise business activities coordination & 0.221012 & -0.240161 & -0.352826 & 0.303943 \\
5 & Coordinate supervisory actions and duties & 0.267664 & -0.175279 & -0.272818 & 0.228598 \\
6 & Adopt site access measures & 0.215613 & 0.349396 & -0.328355 & -0.139898 \\
7 & Use incidents book & 0.253995 & 0.0308669 & 0.224832 & 0.346514 \\
8 & Give instructions & 0.202856 & -0.0226368 & 0.47757 & -0.0770205 \\
9 & Meetings with clients & 0.311546 & 0.0907869 & 0.281358 & 0.258471 \\
10 & Meetings with players & 0.314082 & -0.174394 & 0.220044 & -0.365091 \\
11 & Coordination meetings & 0.353531 & -0.135658 & -0.0346365 & -0.219099 \\
12 & Site visits & 0.288956 & -0.176779 & 0.227659 & -0.19267 \\
13 & Report writing & 0.275195 & 0.419664 & 0.0898641 & 0.247503 \\
14 & Action to take in the event of an accident & 0.187699 & 0.514137 & -0.0265258 & 0.179565 \\
15 & Awareness raising talks & 0.27072 & 0.238011 & -0.117383 & -0.432255 \\
& Percentage variability attributed total 54.46\% & $25.71 \%$ & $10.95 \%$ & $10.27 \%$ & $7.53 \%$ \\
\hline
\end{tabular}




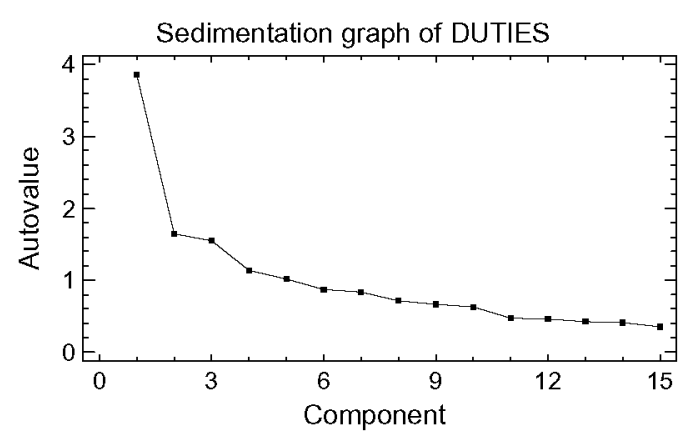

Graph 4. Sedimentation of duties. Own research.

Table 5

Results of the canonical correlation analysis. Own research.

\begin{tabular}{cll}
\hline Canonical correlations & $p$-Value & Correlation coefficient $(\rho)$ \\
\hline 1 & 0.00001 & 0.804298 \\
2 & 0.0006 & 0.619130 \\
3 & 0.0172 & 0.600730 \\
4 & 0.2135 & 0.567088 \\
5 & 0.7414 & 0.442512 \\
6 & 0.8760 & 0.398422 \\
7 & 0.9376 & 0.389777 \\
8 & 0.9878 & 0.336906 \\
9 & 0.9982 & 0.267645 \\
10 & 0.9995 & 0.191580 \\
11 & 0.9993 & 0.136672 \\
12 & 0.9966 & 0.080064 \\
13 & 0.9181 & 0.067749 \\
\hline
\end{tabular}

- If the competencies are analysed separately from the coordination duties, it comes as something of a surprise to see how competencies associated with the coordinator's own personality, such as leadership and self-control, were scored the least by those polled, although they are subsequently scored together with and in relation to other competencies.

- It seems proved that being results-oriented was scored more thinking of another kind of activity rather than coordination itself, although this competence takes on the essence of the ultimate objective in coordination work.

\section{Regarding the DUTIES:}

- It seems proved that the main work of a health and safety coordinator is to visit the site, a duty that is not explicitly stated as part of the coordinator's regulatory duties.
Table 7

Correlation coefficients of the three significant canonical correlations. Own research.

\begin{tabular}{lll}
\hline Variables & Canonical correlation 1 & Correlation coefficient \\
\hline$V_{11}$ & $V_{11}=0.0499 C_{1}+\ldots,+0.1581 C_{13}$ & $\rho_{v_{11} v_{22}}=0.804$ \\
$V_{12}$ & $V_{12}=0.3118 F_{1}+\ldots,+0.1841 F_{15}$ & \\
& Canonical correlation 2 & \\
$V_{21}$ & $V_{21}=0.6362 C_{1}+\ldots,-0.3508 C_{13}$ & $\rho_{\nu_{21} v_{22}}=0.619$ \\
$V_{22}$ & $V_{22}=0.2639 F_{1}+\ldots,-0.2109 F_{15}$ & \\
& Canonical correlation 3 & \\
$V_{31}$ & $V_{31}=0.2696 C_{1}+\ldots,+0.4640 C_{13}$ & $\rho_{\nu_{31} v_{32}}=0.601$ \\
$V_{32}$ & $V_{32}=0.3064 F_{1}+\ldots,-0.4300 F_{15}$ & \\
\hline
\end{tabular}

- Particularly striking is that accident- or general coordinationrelated activities were scored above the mean for duties when this was not the case for duties that can lead to greater responsibilities, such as approving the health and safety plan, giving instructions or coordination meetings.

- In the duties analysis it can be seen that report writing was scored below the mean as the coordinator is not used to doing this kind of duty or obligation and on occasions some coordinators believe they do not have this duty or obligation. However, this score is in contrast to the very high score given to the communication competence.

- Coordination needs to offer added value to the professional job done by a coordinator along those lines. The awareness-raising talks play a major role in coordination work. However, most of those polled do not understand it as a coordinator's duty or obligation, because, among other things, it is not stated so in the regulations.

\subsection{The principal components analysis}

Interpreting the results of this analysis regarding COMPETENCIES, are reflected in the following conclusions:

- In component 1 it can be seen that the variables with most weight have a common hub, since leadership, negotiation and self-control are competencies linked to the coordinator's behaviour and personal skills. It would seem logical to think that to be a leader one needs to know how to negotiate and that to do this needs self-control. This component basically brings together the most representative characteristics of coordinators' personal skills.

- Component 2 contains variables that are closely linked to one another as those of greatest weight, such as effectiveness and efficiency. On the one hand, doing what is needed to meet the

Table 6

Results of the canonical correlation analysis on the variables under study. Own research.

\begin{tabular}{|c|c|c|c|c|c|c|c|c|c|}
\hline \multicolumn{2}{|c|}{ Competencies } & \multicolumn{2}{|c|}{ Correlation 1} & \multicolumn{2}{|c|}{ Correlation 2} & \multicolumn{2}{|c|}{ Correlation 3} & \multicolumn{2}{|l|}{ Duties } \\
\hline 1 & Communication & 0.049998 & 0.311884 & 0.63625 & 0.263916 & 0.269669 & 0.306409 & Coordinate application of safety principles & 1 \\
\hline 2 & Teamwork & 0.217213 & -0.083128 & -0.469544 & 0.136211 & -0.14631 & 0.26241 & Coordinate site activities & 2 \\
\hline 3 & Effectiveness & 0.154552 & 0.099139 & 0.15685 & -0.179228 & 0.456247 & 0.301735 & Approve the $\mathrm{H} \& \mathrm{~S}$ plan & 3 \\
\hline 4 & Efficiency & 0.079193 & 0.248009 & -0.299089 & -0.065689 & 0.169095 & -0.244807 & Organise business activities coordination & 4 \\
\hline 5 & Self-control & 0.090325 & 0.197973 & -0.036014 & -0.302526 & -0.051411 & -0.090861 & Coordinate supervisory actions and duties & 5 \\
\hline 6 & Self-confidence & 0.141153 & -0.100256 & 0.146465 & 0.392789 & -0.635309 & -0.06208 & Adopt site access measures & 6 \\
\hline 7 & Solving conflicts and crises & 0.028656 & 0.073471 & 0.317041 & 0.21517 & 0.011061 & -0.759763 & Use incidents book & 7 \\
\hline 8 & Leadership & 0.094347 & 0.258858 & -0.202574 & 0.298231 & -0.433384 & -0.149026 & Give instructions & 8 \\
\hline 9 & Consultation & 0.139853 & 0.065948 & -0.070915 & -0.093386 & -0.138234 & 0.188781 & Meetings with clients & 9 \\
\hline 10 & Negotiation & -0.019996 & -0.064376 & 0.635514 & -0.065008 & 0.34154 & 0.138928 & Meetings with players & 10 \\
\hline 11 & Results-oriented & 0.401175 & 0.185997 & -0.184568 & 0.501027 & -0.24966 & 0.408644 & Coordination meetings & 11 \\
\hline 12 & Planning and organisation & 0.144699 & 0.11951 & -0.033193 & -0.059486 & -0.07467 & -0.073769 & Site visits & 12 \\
\hline \multirow[t]{4}{*}{13} & Commitment to the project & 0.158081 & 0.229329 & -0.35088 & -0.097951 & 0.464059 & -0.178469 & Report writing & 13 \\
\hline & & & 0.185326 & & -0.709933 & & 0.42004 & Action to take in the event of an accident & 14 \\
\hline & & & 0.184188 & & -0.210919 & & -0.430078 & Awareness raising talks & 15 \\
\hline & & \multicolumn{2}{|c|}{$p$-Value $<0.00001$} & \multicolumn{2}{|c|}{$p$-Value $=0.0006$} & \multicolumn{2}{|c|}{$p$-Value $=0.0172$} & & \\
\hline
\end{tabular}




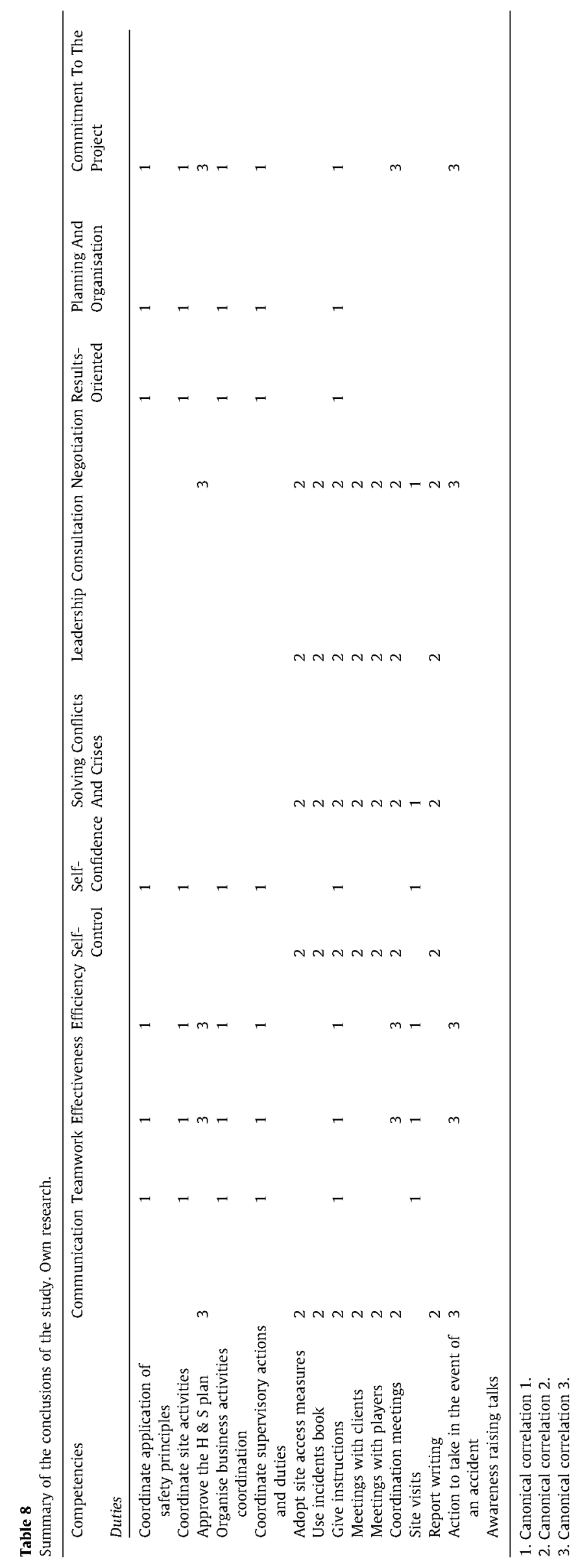

objectives and on the other hand, having the ability to use the resources and know-how to achieve those objectives. A good coordinator must begin by knowing what they need and what they possess in order to be able carry out the health and safety coordination demanded of them.

- Component 3 points out issues related to coordinator's professionalism and their knowledge. The coordinator must establish a job methodology using planning and organisational tools and concepts and must have the ability to get across ideas that improve site coordination to their elected delegates. That is, they must possess the self-confidence required to put forward serious and acceptable points of view for achieving the objectives.

- Another marked aspect in this analysis is the relationship between the groups of variables with most weight (for example, self-control, leadership and negotiation for component 1 , or effectiveness and efficiency for component 2) that are directly related to the highest scored competencies, such as communication and commitment to the project.

- The linear combinations that have given rise to these three principal components account for over $50 \%$ of the variability of the sample.

The interpretation of the results of this analysis concerning DUTIES is reflected in the following conclusions:

- In component 1 it can be seen that the duties that account for a higher degree of variability have a common denominator linked to the coordinator's need to hold meetings in the course of their duty, during the hiring and planning stages and the construction stage, concerning the other players involved.

- Component 2 makes it clear that writing reports of the measures taken in the event of an accident has one objective in common. It would seem logical to underline that the coordinator is involved in these situations and usually works with reports that attempt to explain the causes of any accidents that have happened.

- Component 3 clearly explains the common goal existing between giving instructions and filling in the incidents book. These two duties for coordinators are regulated and are an essential part of coordination work.

- Like the one above, component 4 points out the coordinator's obligation, which has its origins halfway between the incidents book mentioned previously and the comments that should be made in the book to mark the progress and development of the coordination as laid down in the regulations in force, namely RD $1627 / 97$ and Law 32/2006 that govern sub-contracting in the construction sector. That is, carrying out the site and business work that is part of the coordinator's job.

- As with competencies, we should mention the relationship existing between the groups of variables with the greatest weight (for example, meetings for component 1 , or using the incidents book and giving instructions for component 3 ) which are directly related to the most highly scored duties in the descriptive analysis, like site visits and actions taken in the event of an accident.

- The sum of the five principal components calculated for the DUTIES variables, account for over $60 \%$ of the variability of the fifteen duties.

\subsection{Interpreting the canonical correlation analysis}

One of the three most significant canonical correlations is analysed: 
- In "correlation 1" the linear combination of the competencies indicates that those with the greatest weight are teamwork, effectiveness, being results-oriented, planning and organisation and commitment to the project.

In this same canonical correlation the linear combination of the duties set defines coordinating, organising and giving instructions as being the duties with the greatest weight.

How can the coordinator make use of these competencies to strengthen their functions? Or to put it another way, if the coordinator strengthens these competencies, will their coordination work be better? On which functions will there be most repercussion? The answer is to be found in this first canonical correlation analysed.

The health and safety coordinator has one clear objective in common with the other players intervening in construction work; to do the work safely. This means integrating and coordinating workers' health and safety to avoid work accidents. If this is to be achieved the coordinator must be committed to doing a good job by applying their individual work methodology and developing it with the collaboration of all those involved.

Coordination and organisational duties must be performed in collaboration with the companies involved in the construction work. Therefore, teamwork, effectiveness and planning and organisation are clearly related to these tasks. In order to give precise, clear and correct instructions the coordinator must be aware of the objectives and be committed to the job. The instructions must be channelled towards achieving the results stated.

"Correlation 2", is subjected to a similar analysis which reveals another grouping of competencies linked to the duties to be carried out by the coordinator.

Analyses have already been made that show the importance that this leadership can have in generating a climate of trust among workers and its importance for their safety (Conchie et al., 2011).

In this second correlation, the relevant competencies summarise the most usual duties of a coordinator during the course of their work. Here we should like to recall that in the first data analysis, those polled scored duty number 12 (site visits) significantly higher than the mean. It is in these site visits that the expert needs to apply their most personal skills.

Competencies numbers 1 (communication), 7 (conflict solving) and 10 (negotiation) play a very important role in coordination work. So, from the results of this analysis which functions are enhanced through knowing and developing these competencies? From the results analysis we conclude that these functions are numbers 6 (site access control), 8 (giving instructions) and 11 (coordination meetings).

Controlling site access, listed as a mandatory coordination duty, requires a method or procedure to be in place on site so that only authorised personnel can access the site. It may also refer to the machinery or materials, but the coordinator's job is to negotiate an agreement and ensure that this procedure put in place by the acting company in the work centre is adhered to. It is therefore essential that this agreement be reached through a negotiation process. Conflicts can arise and the coordinator can thus act as mediator.

The same applies to coordination meetings where negotiation is an ongoing process, as these meetings are attended by companies, experts, workers and other players from the construction sector. Even more important, if that is possible, is communication, a proven competency that is acclaimed in international coordination forums and the one that integrates health and safety into every site activity and is present on every level.
In this situation, written communication is essential for giving instructions, and as can be seen from the previous interpretation, it must be precise, clear, correct and specific.

- For the third relationship "correlation 3", those polled gave significance to the duties that involved a higher responsibility load due to the consequences they can have on site or in subsequent legal proceedings.

In order to improve this coordination work grouped together in numbers 3 (approving the health and safety plan), 11 (coordination meetings) and 14 (action to be taken in the event of an accident), the analysis again seems to indicate that negotiation and commitment to the project are the competencies with most weight. We might even talk about a moral load in the coordinator's good work and method and all this with the aid of effectiveness. That is, with the ability to achieve the expected or desired outcome after acting, in this case, the act of coordinating.

All duties linked to meetings, coordination, reports and the incidents book will be enhanced by the competencies included in this analysis, such as communication or negotiation. Regarding the competencies that have not been examined, it could be interpreted that these are also involved in those dealt with in this analysis; for example, efficiency or leadership and negotiation and commitment to the project as a part of teamwork.

\section{Conclusions}

From the way the results have evolved and their interpretation it would seem to be proved that there are three competencies that health and safety coordinators deem necessary to strengthen their job performance. These are communication, negotiation, and commitment to the project, all of which hand-in-hand with effectiveness and efficiency.

As to duties, it would also seem to be proved that those requiring a larger number of competencies to be put into practice are site visits, coordination work that applies the general principles of health and safety at work and giving instructions, all of which require twelve of the thirteen competencies for them to be successfully implemented.

Table 8 shows the pairs of duties and competencies that are weighted as relatively important in the canonical correlations.

Having detected the competencies required for the coordinators to effectively perform the duties required of them by law, by carrying out a canonical correlation analysis, we have seen they can be classified into three groups: personal skills, technical competencies and competencies associated with the legal implications that are part of the job.

It has been demonstrated that there are duties that can be better done if the most technical competencies are strengthened.

After completing the analyses, there was a duty that required no specific competence to be developed (awareness-raising talks), and one other competence that required no specific function to be developed (consultation).

Some current training programmes have been found to be deficient in strengthening some of the competencies found to be priority. We propose setting up university training in each competence for health and safety coordinators.

The conclusions drawn from the analyses described in this paper will help guide and establish these training programmes in each competence for Health and Safety Coordinators as a way to help them better perform their duties and hence manage safety in construction works.

The results of these analyses will help set criteria for selecting health and safety coordinators according to their competencies. 


\section{Appendix A}

\section{QUESTIONNAIRE}

Instructions

Two questionnaires $\mathrm{A}$ and $\mathrm{B}$ must be completed, each questionnaire being independent. Each item is scored according to the following scale:

$\begin{aligned} & \text { EVALUATION SCALE } \\ & 1 \text { Of no importance } \\ & 2 \text { Of little Importance } 3 \text { Important } \\ & \text { Essential }\end{aligned}$
Please indicate your qualifications and years of work experience:
QUALIFICATIONS
QUESTIONNAIRE A

Score from 1 to 5 the level of importance you ascribe to each competence required to perform the duties and activities involved in health and safety coordination during the project and execution stages:

\begin{tabular}{|c|c|c|}
\hline 1 & COMMUNICATION & $\begin{array}{l}\text { An effective exchange between the parties so that the } \\
\text { information is understood. }\end{array}$ \\
\hline 2 & TEAMWORK & $\begin{array}{l}\text { A set of strategies, procedures and methodologies that } \\
\text { are used by a group of people to reach the set goals. }\end{array}$ \\
\hline 3 & EFFECTIVENESS & $\begin{array}{l}\text { Doing what is necessary to reach or achieve the set or } \\
\text { desired goals. }\end{array}$ \\
\hline 4 & EFFICIENCY & $\begin{array}{l}\text { The ability to use time and resources in a profitable } \\
\text { manner in order to achieve the agreed work and satisfy } \\
\text { the expectations of the interested parties. }\end{array}$ \\
\hline 5 & SELF-CONTROL & $\begin{array}{l}\text { A systematic and disciplined approach for tackling } \\
\text { everyday work, changes to requirements and stressful } \\
\text { situations. }\end{array}$ \\
\hline 6 & SELF-CONFIDENCE & $\begin{array}{l}\text { The ability to express points of view in an authoritative } \\
\text { way and ensure there is effective communication with the } \\
\text { team. }\end{array}$ \\
\hline 7 & $\begin{array}{l}\text { SOLVING } \\
\text { CONFLICTS AND } \\
\text { CRISES }\end{array}$ & $\begin{array}{l}\text { A conflict may be defined as a clash of interests. A crisis } \\
\text { may be defined as a moment of acute difficulty rather } \\
\text { than what might arise as a result of a conflict. }\end{array}$ \\
\hline 8 & LEADERSHIP & $\begin{array}{l}\text { This involves providing management and motivation to } \\
\text { others for their role or task so that the goals of a project } \\
\text { will be achieved. }\end{array}$ \\
\hline 9 & CONSULTATION & $\begin{array}{l}\text { The competence required for reasoning, putting forward } \\
\text { solid arguments, listening to others points of view, } \\
\text { negotiating and finding solutions. }\end{array}$ \\
\hline 10 & NEGOTIATION & $\begin{array}{l}\text { This is the means whereby the parties can solve their } \\
\text { disagreements to reach a solution that is satisfactory for } \\
\text { all. }\end{array}$ \\
\hline 11 & RESULTS-ORIENTED & $\begin{array}{l}\text { This is being concerned with focusing the group's } \\
\text { attention on key objectives in order to achieve the } \\
\text { optimum result for all the parties involved. }\end{array}$ \\
\hline 12 & $\begin{array}{l}\text { PLANNING AND } \\
\text { ORGANISATION }\end{array}$ & The methodology used by the coordinator. \\
\hline 13 & $\begin{array}{l}\text { COMMITMENT TO } \\
\text { THE PROJECT }\end{array}$ & Integrating prevention into the job context. \\
\hline
\end{tabular}




\section{Appendix B}

\section{QUESTIONNAIRE B}

Score from 1 to 5 the level of importance you ascribe to each competence required to perform the duties and activities involved in health and safety coordination during the project and execution stages:

\begin{tabular}{|c|c|}
\hline 1 & $\begin{array}{l}\text { COORDINATING THE GENERAL PRINCIPLES OF HEALTH AND SAFETY, (RD } \\
\text { 1627/97, article 9a) }\end{array}$ \\
\hline 2 & COORDINATING ON-SITE ACTIVITIES, (RD 1627/97, article 9b) \\
\hline 3 & APPROVIONG THE HEALTH AND SAFETY PLAN, (RD 1627/97, article 9c) \\
\hline 4 & $\begin{array}{l}\text { ORGANISING THE COORDINATION OF BUSINESS ACTIVITIES, (RD 1627/97, } \\
\text { article 9d) }\end{array}$ \\
\hline 5 & $\begin{array}{l}\text { COORDINATING SUPERVISORY ACTIONS AND DUTIES, (RD 1627/97, article } \\
\text { 9e) }\end{array}$ \\
\hline 6 & $\begin{array}{l}\text { ADOPTING THE NECESSARY MEASURES SO THAT ONLY AUTHORISED } \\
\text { PERSONS CAN ACCESS THE WORK SITE (RD 1627/97, article 9f) }\end{array}$ \\
\hline 7 & $\begin{array}{l}\text { Using the INCIDENTS BOOK in the cases stipulated in RD } 1627 / 97 \text { and their } \\
\text { modification in Act 32/2006 regulating sub-contracting in the construction } \\
\text { sector. }\end{array}$ \\
\hline 8 & $\begin{array}{l}\text { GIVING INSTRUCTIONS for the right dynamics and coordination } \\
\text { methodology. }\end{array}$ \\
\hline 9 & MEETINGS WITH CLIENTS to set out the conditions for coordination. \\
\hline 10 & $\begin{array}{l}\text { MEETINGS WITH OTHER PLAYERS in the process who are involved in the } \\
\text { work, prior to the start of the work or during the work. }\end{array}$ \\
\hline 11 & $\begin{array}{l}\text { COORDINATION MEETINGS with the specific players of the companies } \\
\text { involved. }\end{array}$ \\
\hline 12 & SITE VISITS, and their process, working methodology and characteristics. \\
\hline 13 & WRITING REPORTS for the client on coordination actions. \\
\hline 14 & $\begin{array}{l}\text { PROCEDURE IN THE EVENT OF ACCIDENTS when the circumstances advise } \\
\text { such. }\end{array}$ \\
\hline 15 & AWARENESS-RAISING TALKS agreed to by the work centre managers. \\
\hline
\end{tabular}

\section{References}

Andrew, R.J., Dainty, M., Moore, D.R., 2004. A competency-based performance model for construction project managers. Construction Management and Fconomics 22, 877-886.

Ansorena Cao, Alvaro., 1996. 15 casos para la Selección de Personal con Éxito, Barcelona, Paidos Empresa.

Anduiza Arriola, R., Rodríguez Gómez, F., Rosel Ajamil, L., 2001. Comentarios técnicos sobre la coordinación de seguridad y salud en las obras de construcción. Fundación Escuela de la Edificación, Madrid, ISBN 84-86957-89-3.

Anduiza Arriola, R., et al., 2004. El coordinador de seguridad: herramientas para su éxito. Fundación COAAT de Alicante. ISBN: 84-95560-09-7.

Baker, P., 2011. The coordination of safety and health in construction: a key added value for effective prevention. Second European conference on health and safety coordination in the construction industry, Madrid.

Beguería Latorre, P.A., 2002. Método para la coordinación de seguridad y salud en la construcción. Fundación Escuela de la Edificación, Madrid, ISBN 84-86957-91-5.

Boyatzis, R.E., 2009. Competencies as a behavioral approach to emotional intelligence. Journal of Management Development 28 (9)

Boyatzis, R.E., 1982. The Competent Manager: A Model For Effective Performance. Wiley, New York, 1982. No. of pages: 308. ISBN 0-471-09031-X.

Conchie, S.M., Taylor, P.J., Charlton, A., 2011. Trust and distrust in safety leadership: mirror reflections? Safety Science.

CONSEJO DE LA UNIÓN EUROPEA. Comunicación de la Comisión al Parlamento Europeo, al Consejo, al Comité Económico y Social y al Comité de las Regiones: Mejorar la calidad y la productividad en el trabajo: estrategia comunitaria de salud y seguridad en el trabajo (2007-2012). Bruselas, 26 febrero 2007(01.03). $6775 / 07$.

Cook, K.L., Cox, C.J., Henning, S.E., 2008. Breaking the boundaries: standardization of a competency assessment Model for all clinical Disciplines. Nurse leader 6 (3), 34-40.

Crawford, L., 2005. Senior management perceptions of project management competence. International Journal of Project Management 23, 7-16.

Durán López, F., Tudela Cambronero, G., Valdeolivas García, Y., 2007. Informe sobre la situación de la prevención de riesgos laborales en el sector de la construcción en España. Madrid, Edisofer, S.L. Confederación Nacional de la Construcción. ISBN: 84-96261-52-5.

Eicker, S., Kochbeck, J., Schuler, PM., 2007. Employee Competencies for Business Process Management. University of Duisburg-Essen, Faculty of Economics: Chair of Business Informatics and Software Engineering.

Eid, J., Mearns, K., Larsson, G., Laberg, J.C., Johnsen, B.H., 2011. Leadership, psychological capital and safety research: conceptual issues and future research questions. Safety Science.

Escrig-Tena, A.B., Bou-Llusar, J.C., 2005. A model for evaluating organizational competencies: an application in the context of a quality management initiative. Decision Sciences 36 (2), 221-257.

Esteban Gabriel, J., 2011. Tesis Doctoral. Estudio sobre la integración de la prevención en la fase de redacción de los proyectos.

Gareis, R., 2003. Competences of Project-Oriented Companies: A Process-Based Maturity Model. PM Group, Vienna University of Economics and Business Administration.

Jha, K.N., Iyer, K.C., 2007. Commitment, coordination, competence and the iron triangle. International Journal of Project Management 25, 527-540.

Kasvi, J.J., Vartiainen, M., Hailikari, M., 2003. Managing knowledge competences in projects and project organizations. International Journal of Project Management 21, 571-582.

Kwaku, D., Gavi, D., Olomolaiye, P. 2008. Towards developing competency-based measures for construction project managers: Should contextual behaviours be distinguished from task behaviours? International Journal of Project Management 26, 631-645.

Kristensen, P.H., 2011. Managing OHS: a route to a new negotiating order in highperformance work organizations? Safety Science.

Leka, S., Jain, A. Widerszal-Bazyl,M.,Żołnierczyk-Zreda, D.,Zwetsloot, G., 2011.Developing a standard for psychosocial risk management: PAS 1010. Safety Science.

Likert, R., 1932. A technique for the measurement of attitudes. Archives of Psychology 140, 1-55.

Mármol Ortuño, AA. Pérez Herrero, M. 2007 Procedimiento de coordinación de seguridad en la ejecución de obras. AM\&MP, C.B., Murcia. ISBN: 84-89882-24-x. 
Martínez-Córcoles, M., Gracia, F., Tomâs, I., Peiró, J.M., 2011. Leadership and employees' perceived safety behaviours in a nuclear power plant: a structural equation model. Safety Science.

Perona Lucas, J., 2005. Manual del coordinador de seguridad en construcción. COAAT Región de Murcia.

Rodríguez T. Nelson, Feliú S. Pedro, 1996a. Manual Descriptivo y de Aplicación de la Prueba de Estilo Gerencial (PEG 01).

Rodríguez T. Nelson, Feliú S. Pedro, 1996b. Manual de prospección en Ventas FORD. Caracas.

Rose, J., Pedersen, K., Hosond, J.H., Kraemmergaard, P., 2007. Management competences, not tools and techniques: a grounded examination of software project management at WM-data. Journal of Information and Software Technology 49, 605-624.

Schmeidinger, B., 2005. Competency based business development: organizational competencies as basis for the successful companies. Journal of Universal Knowledge Management 1, 13-20.

Segarra Cañamares, M., Amat Batlle, S. 2011. Ponencia $2^{\circ}$ Coloquio Europeo sobre coordinación de seguridad y salud en la construcción, Madrid 2011. Formación universitaria en competencias del coordinador de seguridad y salud.

Shirazi, A., Mortazavi, S., 2009. Effective management performance: a competencybased perspective. International Review of Business Research Papers 5 (1), 110 .
Spencer, L.M., Spencer, S.M., 1993. Competence at Work. John Wiley and Sons, New York.

Törner, M., 2011. The "social-physiology" of safety. An Integrative Approach to Understanding Organisational Psychological Mechanisms Behind Safety Performance. Safety Science.

Udo, N., Koppensteiner, S., 2004. What are the Core Competencies of a SUCCESSFUL PROJECT MANAGER? PMI Global Congress Proceedings - Prague, Hungary.

Vedsmand, L., 2011. New elements of coordinators' training, competencies and skills. Second European conference on health and safety coordination in the construction industry. Madrid.

Woodruffe, Charles, 1993. What is meant by a Competency? Leadership and Organization Development Journal $14(1), 29-36$.

Zibell, L., 2007. Measuring collective competencies of organisations - a systematic review of literature. MRes in Management Research. Cranfield University.

Zwetsloot, G., Hale, A., Zwanikken, S., 2011a. Regulatory risk control through mandatory occupational safety and health $(\mathrm{OSH})$ certification and testing regimes (CTRs). Safety Science.

Zwetsloot, G., Zwanikken, S., Hale, A., 2011b. Policy expectations and the use of market mechanisms for regulatory OSH certification and testing regime. Safety Science. 